Rev. Biol. Trop. 52(1): 213, 2004

www.ucr.ac.cr www.ots.ac.cr www.ots.duke.edu

NOTE

\title{
Collection of Dermophis parviceps (Gymnophiona: Caeciliidae) from underground mud nests in Guayacán, Costa Rica
}

\author{
Brian Kubicki ${ }^{1} \&$ Maximillion Flores Reyes ${ }^{2}$ \\ 1 Costa Rican Amphibian Research Center, Apartado Postal 81-7200 Siquirres, Limón Province, Costa Rica; acropo- \\ ra@ racsa.co.cr \\ 2 Costa Rican Amphibian Research Center, Guayacán de Siquirres, Limón Province, Costa Rica.
}

$$
\text { Received 03-VI-2003. Corrected 25-VII-2003. Accepted 01-VIII-2003. }
$$

Recently, three specimens of Dermophis parviceps were collected on the private reserve of the Costa Rican Amphibian Research Center, Guayacán de Siquirres (N 1002'58.1” W 83³2’31.2”), Limón Province, Costa Rica. The specimens were discovered on April 28th, 2003 , while digging a pond in a sector of secondary forest. The site is classified as Tropical Premontane Rain Forest (Holdridge 1967), with an altitude of approximately 520 meters.

Each specimen was found alone in a cavity formed of dense clay, at a depth of 50-65 cm below the surface of the soil. Two of the structures were destroyed while attempting their removal, but one was extracted partially intact. The structure contained a small spherical cavity roughly the size of a baseball. The walls were covered with an extremely fine mud, which had a color and texture very different from the surrounding soil in the area. Exit holes out of the cavity were not seen, but they could have been easily overlooked. Whether these cavities were used as nests for reproduction is not known. There is no previous report of this species constructing nests (Savage 2002).

The specimens were sexed and measured by Gerardo Chavez in the University of Costa Rica's Museum of Zoology. Two of the specimens were females, one with a length of 255 $\mathrm{mm}$ and the other with a length of $223 \mathrm{~mm}$. The third specimen was a male, with a length of $271 \mathrm{~mm}$.

\section{REFERENCES}

Holdridge, L.R. 1967. Life Zone Ecology. Rev. ed. San José: Tropical Science Center.

Savage, J.M. 2002. The Amphibians and Reptiles of Costa Rica. The University of Chicago, Chicago, USA. 934 p. 
